\title{
Development of Innovative Creative Character instruments for students in Denpasar
}

\author{
Devi Rahmawati ${ }^{{ }^{*}}$, Nyoman Dantes ${ }^{2}$, Ni Ketut Suarni ${ }^{3}$ \\ 1,2,3 Universitas Pendidikan Ganesha \\ *Corresponding author, e-mail: devira041293@gmail.com
}

Received August 02, 2021; Revised August 31, 2021; Accepted Sept. 20, 2021; Published Online 2021-10-01

\section{Conflict of Interest} Disclosures:

The authors declare that they have no significant competing financial, professional or personal interests that might have influenced the performance or presentation of the work described in this manuscript.

\begin{abstract}
The purpose of this study is to develop and test the feasibility of innovative creative instruments, so as to produce valid and reliable data in measuring innovative creative characters. The innovative creative character instrument is a measuring tool for counseling teachers to determine the level of innovative creative character in students. This study uses the method Research and Development. Based on the validity test using the product moment formula and reliability using the Cronbach alpha formula, this innovative creative character instrument that has been developed has met the validity and reliability criteria which can be classified as high. It can be concluded that the development of creative and innovative character instruments for high school/vocational high school students meets the validity standard for measuring innovative creative characters in high school/vocational high school students.
\end{abstract}

Keywords: Innovative Creative Character, Validity \&Reliability, R\&D.

\section{Introduction}

Education is a means that can be used for the cultivation of creative and innovative characters. The role of education in producing innovative creative individuals is stated in Law No. 20 of 2003 on the national education system article 3 which states that national education serves to develop capabilities and form the character and civilization of a dignified nation in order to educate the life of the nation, aiming to develop learners in order to become human beings who believe and fear God Almighty, noble, healthy, knowledgeable, capable, creative, independent and become a democratic and responsible citizen. 
Innovative creative character should be owned by students in the 21 st Century because it is a time when all aspects of life are growing. Starting from technology, science, social, economic, and education. Developments that occur require people to have life skills in the 21st century included in the scope of learning and innovating skills, which include critical thinking and problem solving, communication and collaboration, as well as creativity and innovation. It is clear that creative character and innovation need to be possessed at this time.

Science and technology are always evolving according to their respective eras, so the quality of education from time to time always increases higher than before. Starting from the Era of Revolution 1.0, 2.0, 3.0 until now is in the Era of Industrial Revolution 4.0 with a very rapid acceleration of science. In this Era of Industrial Revolution 4.0, education becomes very important to develop students have creative and innovative skills.

Research conducted by Yudha, Dafik, \&Yuliati (2018) shows that no student reaches the level 0 level of creative thinking, so this means that students do not master creative and innovative skills in problem solving. (Mukhlis \&Tohir, 2019) While the results of research obtained by Zubaidah (2018) show that the main domain of 21 st century skills in the form of digital literacy, intensive thinking, effective communication, high productivity and spiritual and moral values can be achieved through continuous exercises in the learning process tailored to the characteristics of students. (Redhana, 2019).

Based on the interview that researchers conducted at SMA AL-MA'RUF Denpasar, it was found that high school students who should be in accordance with the stage of development are able to solve their own problems, able to think creatively with different points of view in understanding an event is still very minimal students who are able to develop themselves in accordance with the stage of development and students are also not able to solve problems in their daily lives. In addition, BK teachers also do not understand the importance of character education, one of which is innovative creative character and BK teachers are still lay related to what are the indicators and how to develop innovative creatives in students.

Still a problem in the field today is an educational system that tends to be academic that tends to only develop the left brain such as reading, writing, counting or logical thinking, rational, or just memorizing.so as to ignore the development of the right brain such as drawing, playing music, playing plays that are rarely to be done. Thus there is an imbalance of left and right brain function. Until the decrease in creativity (creativity drop)in children as reported by Torrance (Rachmawati and kurniati, 2010:26).

Developing children's creativity requires an important role of educators this is generally understood. Creative children satisfy their curiosity through various ways such as exploring, experimenting, and asking questions to others. Suratno (2005:19) explains "creative and intelligent children are not formed by themselves but need to direct one of them by providing activities that can develop this creativity owned by students in general is still low. This can be known by the number of people who have not been able to produce their own work. They still imitate other people's riches. The situation is caused by a lack of creativity development.

Life is increasingly advanced characterized by complex and complex problems. The variety of daily life to the life of the world is related to the rapid and abundant development of information and increasingly sophisticated technology. This implies that education should be able to create adaptive graduates. The step that can be done in order to create adaptive graduates is to develop thinking skills through character building in the learning process, is a core part of the learning process so that students have competence in solving related problems in daily life. Students without character will certainly have the impact of failure in dealing with the complexity of problems encountered in the challenges of a growing age.

Teachers play an important role in realizing educational goals in developing creative character in students. But the fact that happened according to Siswoyo (2014) mentions that:

"As many as 130 high school teachers were unable to direct the development of students' innovative creative character. They think that understanding innovative creative character development is difficult. (Khalifudin et al., 2019)". This is due to a lack of understanding of what innovative creative dimensions can be measured. Many teachers fail to formulate what kind of innovative creative character constructs will be measured. This condition becomes difficult because measuring something will be difficult if it is not yet known what to measure so that the assessment is subjective. 
Innovative creative character instruments should be owned by teachers because they have benefits not only for students but for teachers themselves. Treffinger (Starko, 2010, p.284) argues that the importance of innovative creative character instruments is as follows: (1) Helping students realize their advantages; (2) Developing students' understanding of human abilities, especially about the relationship of innovative creative characters with intelligence;(3) Can be used as an entry point or base line for teachers in developing further services;(4)Evaluating teacher performance during the service process;(5) Understanding the hidden potentials of student creativity and innovation;(6) Eliminating the notion that innovative creative characters are difficult to develop mysteries.

Creative character to solve problems will certainly eventually create innovation as the solution. Basically innovation can be obtained by trying to understand the things that are not yet clear, open with new experiences and ideas and continue to develop capabilities in the face of existing changes. That way it will be easier for students to find unusual ideas as the solution. High school students already have more mature thinking so can already be encouraged to accept unusual new ideas. High school age students can already be instilled that any problem can be solved in an easier and better way. Therefore, Innovative creative character is very important and must be developed as early as possible in order to be better prepared in the face of work or society.

Based On The Description Above The Researchers Want To Conduct A Study With The Title, " Development Of Innovative Creative Character Instruments For High School Or Vocational Students In Denpasar"

Based on the background of the above problems, it can be formulated problems that can be identified in this study are: 1 . How the stage of development of innovative creative character instruments in high school / vocational school in Denpasar). 2. How the Validity of Content And Empirical Validity of Innovative Creative Character Instruments In High School / Vocational School In Denpasar 3. How The Reliability of Innovative Creative Character Instruments In High School / Vocational School In Denpasar.

In line with the formulation of the problem, the purpose of this study is: 1 . Knowing the Stage of development of Innovative Creative Character Instruments in High School / Vocational School In Denpasar 2. Knowing the Validity of Content And Empirical Validity of Innovative Creative Character Instruments In High School / Vocational School In Denpasar 3. Knowing the Reliability of Innovative Creative Character Instruments In High School / Vocational School In Denpasar City.

\section{Method}

\section{Research Design}

This research includes the type of research and development (Research \&Development). Research and Development method is a research method used to produce a particular product and test the effectiveness of the product. In developing the concept of creative and innovative character instruments guided by 10 steps initiated by Anastasi Dantes, namely: (1) set the purpose of the test (2) book analysis and learning resources (3) create a grid (4) product design (5) validation concept (6) product revision (7) limited reproduction (8) test (9) analysis of the test results (10) assemble the question.

\section{Research Subject}

The study subjects were respondents who were sampled in a study. Research subjects can also be interpreted as individuals who are used as a source of data or sources of information by researchers in conducting research. The subjects in this study were grade XI students at AL-Ma'ruf High School and SMK IT GLOBAL Denpasar. Research conducted on grade XI students is due to the need to strengthen the innovative creative character in grade XI students so as to develop innovative creative character in daily life.

\section{Data Analysis}

The data analysis techniques used in this study are validation tests and reliability tests. Content validation test means that it will analyze the information / data that has been obtained from the expert test scores as many as 3 Undiksha Professors and educational practitioners as many as $2 \mathrm{BK}$ teachers in the test using lawshe CVR test, for internal validation test items using product moment formula and for reliability test using Cronbach alpha formula. 


\section{Results and Discussion}

The result of the research development that has been done is in the form of Innovative Creative Character Instruments. The development of innovative creative character questionnaires using the steps of Anastasi Dantes is to set test objectives, analyze books and relevant sources, create product grids and validate concepts. Based on the results of the analysis of research data conducted on 45 students at SMA AL-Ma'ruf and SMK TI Global using Lawshe CVR test with the formula:

$$
C V R=\frac{n e-\frac{N}{2}}{\frac{N}{2}}
$$

Obtained a value item $(C V R>0)$, then the value of CVI obtained a value of 0.9 , this value means that the index of the validity of the contents of the 40 points of the problem in the instrument character Innovative creative character is very valid or very good. After doing cvr test followed by calculation of validity test of question item by using Product Moment with formula:

$$
r_{x y}=\frac{N \sum X Y-\left(\sum X\right)\left(\sum Y\right)}{\sqrt{\left\{N \sum X^{2}-\left(\sum X\right)^{2}\right\}\left\{N \sum Y^{2}-\left(\sum Y\right)^{2}\right\}}}
$$

Product moment is used to know the level of validity, the testing criteria are the criteria of the question item in the category of valid if $r_{\text {hit }}>r_{\text {tab }}$ on significant $5 \% \mathrm{~N}=45$, then $r_{\text {tab }}$ obtained 0.294 . judging from the calculation results then from 40 points of question there is 1 item of the question that is declared dead that is point number 2 because $r_{\text {hit }}<r_{\text {tab }}$ and 39 questions are declared valid. After the results of the validity of the item continued reliability test to know reliability by using Alpha Cronbach with the formula:

$$
\left(\frac{k}{k-1}\right)\left[1-\frac{\sum S D i}{S D t}\right]
$$

The reliability coefficient of $r_{\text {hit }}$ is 1.0 can be seen in table 1 . This shows that the level of reliability of Innovative Creative character instruments is very high, so the product of Innovative Creative character instrument is important to be developed and applied as one of the supporting instruments in counseling guidance services.

Reliability Test Of Innovative Creative Character Instruments

$$
\begin{aligned}
& S D t=\sqrt{\frac{N \sum X^{2}-\sum(X)^{2}}{N(N-1)}} \\
& S D t=\sqrt{\frac{45(786401)-(5919)^{2}}{45(44)}} \\
& S D t=\sqrt{\frac{35388045-35034561}{1980}} \\
& S D t=\sqrt{\frac{353484}{1980}} \\
& S D t=\sqrt{178.5272727} \\
& S D t=13.361
\end{aligned}
$$


Next:

$$
\begin{aligned}
& r_{i i}=\left(\frac{39}{39-1}\right)\left[1-\frac{\sum S D i}{S D t}\right] \\
& r_{i i}=\left(\frac{39}{38}\right)\left[1-\frac{37}{13.361}\right] \\
& r_{i i}=(1.026)[1-0.002] \\
& r_{i i}=(1.026)[0.998]
\end{aligned}
$$

$$
r_{i i}=1.0
$$

After knowing the results of CVR conducted empirical validity test on high school and vocational students with the number of students 45 people and this test using the formula Product Moment and obtained the results of the calculation then from 40 points of the question there is 1 point of the question that was declared dead namely point number 2 because rhit $<$ rtab and 39 points of questions declared valid in use. After the results of the validity of the item continued reliability test to know the reliability by using Alpha Cronbach in getting the reliability coefficient of rhit is 1.0 It shows that the level of reliability of innovative creative character instrument is very high, so the product of Innovative Creative character instrument is important to be developed and applied as one of the supporting instruments in counseling guidance services.

\section{Conclusion}

Research of innovative creative character instruments that researchers develop is a research development with research and develoment $(\mathrm{R} \& \mathrm{D})$ method. The product developed in the form of innovative creative character assessment instruments and developed in the form of likert scales used to measure innovative creative characters is then described into indicators that fit the operational definition. To know the feasibility of this innovative creative character instrument conducted expert tests by 5 experts from the field of Guidance and Counseling, After being calculated, obtained the results of CVI value of innovative creative character instruments based on the assessment of 5 experts is 0.9 . this value means the validity of the content of innovative creative character instruments is Very Valid. After knowing the results of CVR conducted empirical validity test on high school and vocational students with the number of students 45 people and this test using the formula Product Moment and obtained the results of the calculation then from 40 points of the question there is 1 point of the question that was declared dead namely point number 2 because rhit $<\mathrm{rtab}$ and 39 points of questions declared valid in use. After the results of the validity of the item continued reliability test to know the reliability by using Alpha Cronbach in getting the reliability coefficient of rhit is 1.0 It shows that the level of reliability of innovative creative character instrument is very high, so the product of Innovative Creative character instrument is important to be developed and applied as one of the supporting instruments in counseling guidance services.

\section{Acknowledgment}

I would like to thank Prof. Dr. Nyoman Dantes as the one supervisor who has provided guidance, direction and advice in completing this research and Mrs. Prof. Dr. Ni Ketut Suarni, M.S., Kons. As a two mentor who has provided guidance, direction and motivation in completing research on the development of innovative creative character instruments in high school /vocational school in Denpasar. 


\section{References}

Amtiningsih, S., Dwiastuti, S., \& Puspita Sari, D. (2016). Peningkatan Kemampuan Berpikir Kreatif melalui Penerapan Guided Inquiry dipadu Brainstorming pada Materi Pencemaran Air Improving Creative Thinking Ability through Guided Inquiry Combined Brainstorming Application in Material of Water Pollution. Proceeding Biology Education Conference, 13(1), 868-872.

Arikunto, S. (2010). Prosedur Penelitian Suatu Pendekatan Praktik. Jakarta: Rineka Cipta.

Asmawati, L. (2017). Peningkatan Kreativitas Anak Usia Dini Melalui Pembelajaran Terpadu Berbasis Kecerdasan Jamak. JPUD - Jurnal Pendidikan Usia Dini, 11(1), 145-164. https://doi.org/10.21009/jpud.111.10

Budiarti, Y. (2015). Pengembangan Kemampuan Kreativitas Dalam Pembelajaran. PROMOSI (Jurnal Pendidikan Ekonomi), 3(1), 61-72. https://doi.org/10.24127/ja.v3i1.143.

Dharmawan, N. S. (2014). Implementasi Pendidikan Karakter Bangsa Pada Mahasiswa Di Perguruan Tinggi. Makalah Disampaikan Pada Pembinaan Pendidikan Karakter Bagi Mahasiswa PTS Di Lingkungan Kopertis Wilayah VIII, 1.

Fajar, Y. W., \& Izzah, L. (2015). Upaya meningkatkan kreativitas anak melalui metode menggambar di desa karangasem kabupaten lamongan. Jurnal PG-PAUD Trunojoyo, 1(1), 4-5.

Fatmawati, J. (2018). Telaah kreativitas. Universitas Airlangga, October, 021.https://www.researchgate.net/publication/328217424_TELAAH_KRE ATIVITAS

Hendryadi, H. (2017). Validitas Isi: Tahap Awal Pengembangan Kuesioner. Jurnal Riset Manajemen Dan Bisnis (JRMB) Fakultas Ekonomi UNIAT, 2(2), 169-178.https://doi.org/10.36226/jrmb.v2i2.47

Heye, D. (2006). Creativity and innovation: Two key characteristics of the successful 21st century information professional. Business Information Review, 23(4), 252257.https://doi.org/10.1177/0266382106072255

Hidayat, S., Hendrayana, A., Pembelajaran, T., Universitas, P., \& Ageng, S. (2018). Penerapan Model Pembelajaran Berbasis Proyek Dengan Hasil Belajar Siswa Sekolah Dasar ( The Uses of

Project-Based Learing Model by Utilizing ICT Media to Increase the Creativity and Student' s Learning Outcome in Primary School ). November, 131-139.

Khalifudin, U. A., Prambudi, A., \& ... (2019). Meningkatkan Kemampuan Berpikir Kreatif dan Rasa Ingin Tahu Melalui Model DL Berbantuan Kartu Domino Materi Operasi Bilangan Pecahan Kelas VII. PRISMA, Prosiding Seminar Nasional Matematika, 2, 778-787. https://journal.unnes.ac.id/sju/index.php/prisma/article/view/29269

Kurniawan, A. (2015). Pendidikan Karakter di Pondok Pesantren dalam Menjawab Krisis Sosial. Edueksos: Jurnal Pendidikan Sosial Dan Ekonomi, 4(2), 1-19.

Lawshe, C. H. (1975). a Quantitative Approach To Content Validity. Personnel Psychology, 28(4), 563-575. https://doi.org/10.1111/j.1744-6570.1975.tb01393.x

Monalisa, P., \& Sukarni, W. (2019). Analisis Karakter "Kreativitas" siswa kelas VIII SMPN 08 Kota Jambi. Publikasi Pendidikan, 9(2), 134. https://doi.org/10.26858/publikan.v9i2.9014

Mukhlis, M., \& Tohir, M. (2019). Instrumen Pengukur Creativity And Innovation Skills Siswa Sekolah Menengah di Era Revolusi Industri 4.0. Indonesian Journal of Mathematics and Natural Science Education, 1(1), 65-73. https://doi.org/10.31219/osf.io/g2hcr

Redhana, I. W. (2019). Mengembangkan Keterampilan Abad Ke-21 Dalam Pembelajaran Kimia. Jurnal Inovasi Pendidikan Kimia, 13(1).

Sit, M., Khadijah, Nasution, F., Wahyuni, S., Rohani, Nurhayani, Sitorus, A. S., \& Armayanti, R. (2016). Pengembangan Kreativitas Anak Usia Dini Pengembangan Teori dan Praktik. In Perdana Publishing.

Sudarmin, Sumarni, W., Mursiti, S., \& Sumarti, S. S. (2020). Students' innovative and creative thinking skill profile in designing chemical batik after experiencing ethnoscience integrated science technology engineering mathematic integrated ethnoscience (ethno-stem) learnings. Journal of Physics: Conference Series, 1567(2). https://doi.org/10.1088/1742-6596/1567/2/022037

Suyitno, H., \& Suyitno, A. (2018). Building innovative and creative character through mathematics. AIP Conference Proceedings, 1941(March). https://doi.org/10.1063/1.5028100

Tarnoto, N., \& Purnamasari, A. (2009). Perbedaan kreativitas siswa SMPN 2 Moyudan ditinjau dari tingkat pendidikan ibu. Humanitas.

Yulianti, Y., \& Saputra Suhandi, D. (2019). Instrumen Penilaian Berpikir Kreatif Pada Pendidikan Abad 21. Jurnal Cakrawala Pendas, 5(2), 40- 44 
Article Information (Supplementary)

\section{Conflict of Interest Disclosures:}

The authors declare that they have no significant competing financial, professional or personal interests that might have influenced the performance or presentation of the work described in this manuscript.

Copyrights Holder: <rahmawati $><2021>$

First Publication Right: BISMA The Journal of Counseling

https://doi.org/10.xxxx/ $\mathbf{x x x x x}$

cc) creative

Open Access Article | CC-BY Creative Commons Attribution 4.0 International License.

Word Count: 